\title{
Extraocular muscle cysticercosis mimicking idiopathic orbital inflammation: case report
}

\author{
Cisticercose muscular extra-ocular simulando inflamação idiopática orbitá ria: \\ relatodecaso
}

\author{
Hélio Angotti-Neto \\ Allan Christian Pieroni Gonçalves ${ }^{2}$ \\ Frederico Castelo Moura ${ }^{3}$ \\ Mário Luiz Ribeiro Monteiro ${ }^{4}$
}

\begin{tabular}{|l|}
\hline ABSTRACT \\
\hline Presentation of one case of extraocular muscle enlargement caused by \\
cysticercosis, its clinical, diagnostic and treatment aspects, and review of \\
the literature on this theme. A female 38-year-old patient with extraocular \\
muscle enlargement and a small cystic lesion at the superior rectus muscle \\
insertion was treated with oral prednisone for almost one year, with a non- \\
specific inflammation of right orbit diagnosis. There were important ocular \\
motility restriction and pain. Computerized tomography disclosed a supe- \\
rior rectus muscle thickening with a small cystic and apparently empty \\
lesion at the muscle's insertion. Excisional biopsy and histopathological \\
study confirmed the clinical suspicion of cysticercosis. There was partial \\
resolution of the restricted motility. Extraocular muscle cysticercosis is the \\
most common site of this disease when involving the orbit. Oral albendazole \\
and prednisone are efficient, but a long history of disease can lead to \\
important residual ocular motility restriction.
\end{tabular}

Keywords: Taenia solium; Cysticercosis; Eye infections, parasitic/diagnosis; Tomography, x-ray computed; Ocular motility disorders; Prednisone/therapeutic use; Albendazole/ therapeutic use; Cases reports [publication type]

\section{INTRODUCTION}

Although the differential diagnosis of extraocular muscle enlargement is extensive, including Graves' orbitopathy, myositis, carotid cavernous fistula, lymphoma, metastatic and primary tumours, when associated with other clinical signs such as lid retraction or pain on eye movement, a correct diagnosis can usually be established ${ }^{(1)}$. We recently examined a patient treated for more than one year with a presumed diagnosis of idiopathic orbital inflammation that was later found to have orbital cysticercosis. This case serves to emphasize that cysticercosis should be included in the differential diagnosis of extraocular muscle enlargement, especially in cases of orbital inflammation non-responsive to corticosteroid treatment.

\section{CASE REPORT}

A 38-year-old female patient was referred to us with a one-year history of right sided orbital pain, lid edema, ocular hyperemia and marked restriction of right eye downgaze. She was treated with high-dose oral prednisone for one year with only some transient amelioration of pain, hyperemia and edema but without a dramatic clinical improvement and with recurrence when tapering the medication. Her past medical history and general physical examination were unremarkable. 
On examination visual acuity was 20/20 in each eye. Prisma and Cover Test disclosed a 35 prism diopter right hypertropia and a 25 prism diopter exotropia when fixing with the left eye. A marked limitation of right infraduction could be assessed with a forced duction test. After rectracting the upper eyelid a possibly cystic lesion at the superior rectus muscle insertion was observed. Exophthalmometry disclosed a $3 \mathrm{~mm}$ right proptosis and the ophthalmic examination was unrevealing.

Because of the atypical restriction on downgaze and unresponsiveness to corticosteroid treatment, imaging studies were reviewed. Computerized tomography (CT) scans disclosed a small cystic round lesion associated with a marked superior rectus muscle enlargement that had been present in two previous CT scans but had been overlooked (Figures 1 and 2). No other abnormalities were found on imaging or laboratory investigations. An excision biopsy was indicated and carried out through a right upper fornice conjunctival incision. At surgery a cyst was found near the insertion of the superior rectus muscle. Its mucoid content and capsule were

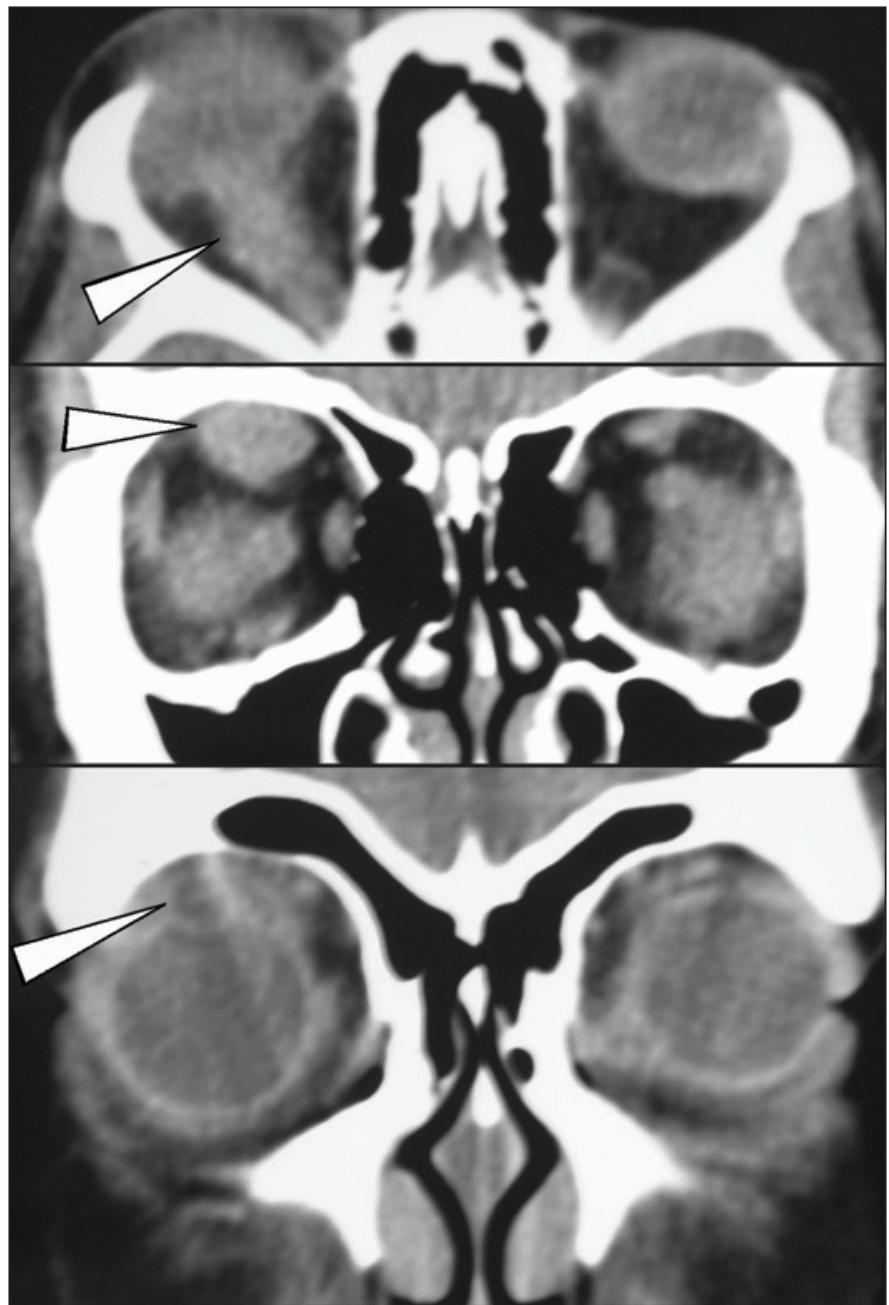

Figure 1 - Computerized tomography of orbits early in the course of the disease showing enlargement of the superior rectus muscle on axial (above) and coronal cuts (middle and below). Notice an ill-defined round lesion near the enlarged muscle insertion at the globe (below). sent to histopathological study that confirmed the diagnosis of cysticercosis infection. A parasitologic examination was negative, and oral steroids were gradually tapered and removed. Right eye restriction improved partially, remaining a 20 diopter right hypertropia with a 15 diopter exotropia when fixing the left eye in Prisma and Cover Test.

\section{DISCUSSION}

Cysticercosis is found equally among both sexes, and can be diagnosed at any age from 5 to 76 years. It represents a heavy social burden in developing countries, reaching a 50million world prevalence according tho the Centers for Disease Control, and leading to 50 thousand deaths each year ${ }^{(2)}$. The neurologic manifestation of this disease can kill $15 \%$ of the patients, and an understimated calculation of patient number of two localities in the state of São Paulo resulted in a prevalence coefficient of 72 to 96 for each 100.000 inhabitants for all manifestations ${ }^{(3)}$.

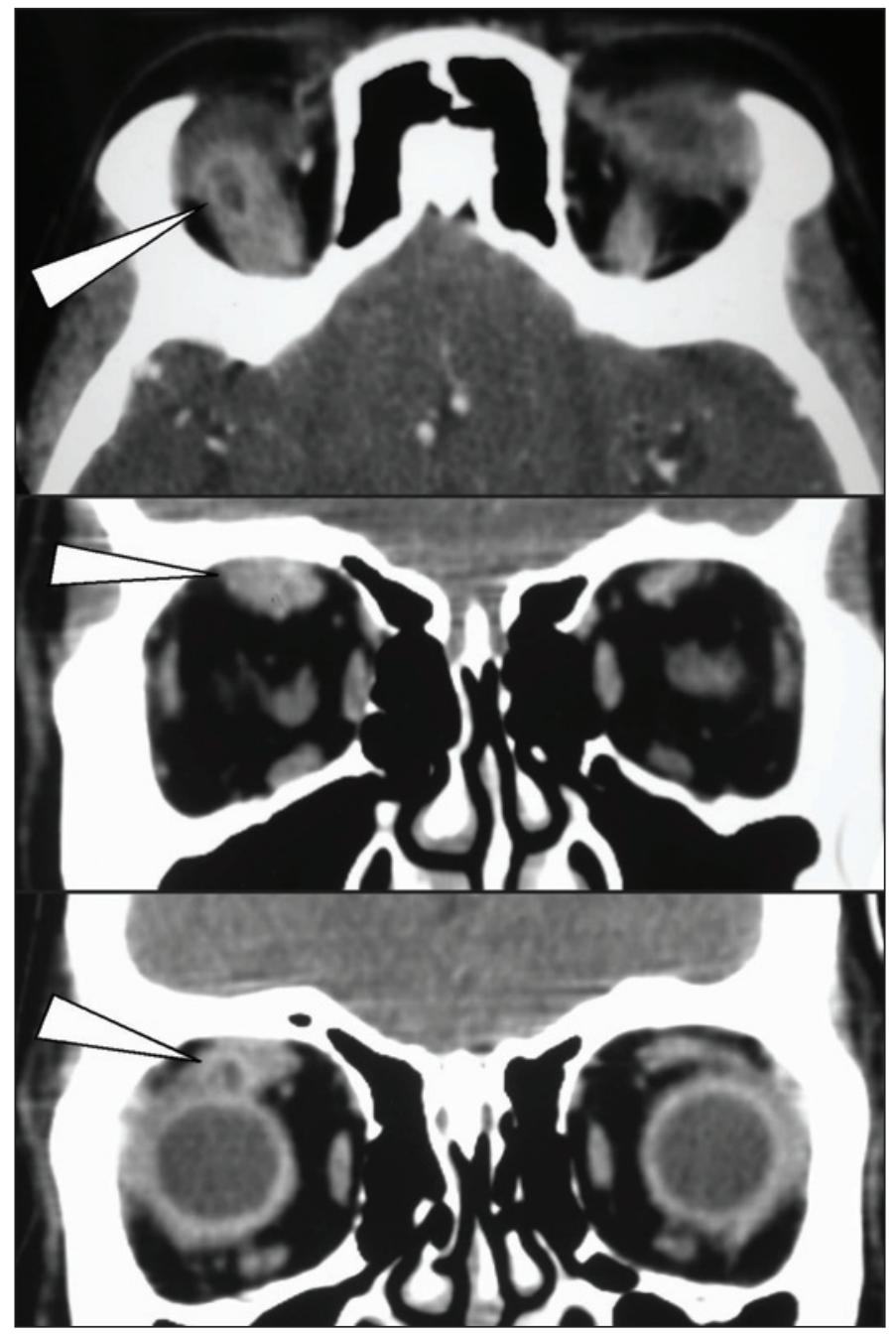

Figure 2 - Computerized tomography of orbits showing enlargement of the superior rectus muscle and cystic lesion located anteriorly in the enlarged muscle insertion 
Cysticercosis usually affects highly vascularized tissues such as the brain, the mastigatory muscles, the tongue and the heart. It is caused by Cysticercus cellulosae, in a resting stage of the Taenia solium larvae in the intermediate host ${ }^{(4)}$ and infects the orbit and adnexa at 5 to $8.4 \%$ of all ophthalmic cases $^{(5-6)}$. It is most commonly found in the extraocular muscles $^{(7)}$ leading to restricted eye movements and inflammatory signs ${ }^{(4)}$ as exemplified by our case in which the superior rectus was affected leading to marked hypertropia and limitation of infraduction.

Imaging studies such as B scan ultrasonography, magnetic resonance imaging and CT scan can be helpful especially when a cystic formation or calcification inside the muscle is documented. Such findings however, may be very discrete and overshadowed by the marked enlargement of the muscle, usually extending far beyond the cyst, as it occurred in our case (Figures 1 and 2).

Early treatment with oral albendazole, corticosteroids and cyst removal is successful in restoring normal function ${ }^{(4,8)}$. However, motility restriction deficits can persist when the diagnosis is delayed, enforcing the need of an early diagnosis.

Among the differential diagnosis, Grave's disease is found in the largest group of patients with enlarged extraocular muscles. Many signs like bilateral disease, more than one muscle enlargement and lid retraction can increase the clinical suspicion of a Grave's disease diagnosis. Another important condition is the myositic form of idiopathic inflammation of the orbit, coursing with pain, muscle enlargement including its insertion and an optimal response to corticotherapy. Less frequent conditions include arteriovenous fistulas and malformations and orbital tumors ${ }^{(9)}$.

Our case therefore serves to emphasize that cysticercosis should be included in the differential diagnosis of extraocular muscle enlargement to attain an early recognition and adequate treatment.

\section{RESUMO}

Apresentação de um caso de aumento de músculo extra-ocular causado por cisticercose, seus aspectos diagnósticos, clí- nicos, tratamento e revisão da literatura sobre o tema. Paciente de 38 anos do sexo feminino com aumento de músculo reto superior e pequena lesão cística foi tratada por um ano com prednisona oral com o diagnóstico de inflamação inespecífica da órbita. Havia importante restrição da motilidade ocular e dor. Tomografia computadorizada demonstrou espessamento do reto superior e pequena lesão cística, aparentemente sem conteúdo, na inserção do músculo. Biópsia excisional e estudo histopatológico confirmaram a suspeita de cisticercose. Houve melhora parcial da restrição de motilidade. A cisticercose de músculo extra-ocular é a mais frequente forma orbitária da doença. Tratamento clínico com albendazol e prednisona é eficiente, mas um atraso no diagnóstico pode levar a importante restrição residual na motilidade ocular.

Descritores: Taenia solium; Cisticercose; Infecções oculares parasitárias/diagnóstico; Tomografia computadorizada por raios x; Transtornos da motilidade ocular; Prednisona/uso terapêutico; Albendazol/uso terapêutico; Relatos de casos [tipo de publicação]

\section{REFERENCES}

1. Monteiro ML. Liposarcoma of the orbit presenting as an enlarged medial rectus muscle on CT scan. Br J Ophthalmol. 2002;86(12):1450.

2. Pedretti Jr L, Bedaque EA, Morales JS, Brutto OH. Cisticercose. In: Veronesi R, Focaccia R. Tratado de Infectologia. São Paulo: Atheneu. 1999. p.1332-47.

3. Agapejev S. Aspectos clínico-epidemiológicos da neurocisticercose no Brasil: análise crítica. Arq. neuropsiquiatria. 2003;61(3B):822-8.

4. Pushker N, Pushker N, Bajaj MS, Chandra M, Neena. Ocular and orbital cysticercosis. Acta Ophthalmol Scand. 2001;79(4):408-13.

5. Wittig EO. Ocular cysticercosis: an epidemiological study. Arq Neuropsiquiatri, 2001;59(3-B):696-701.

6. Atul K, Kumar TH, Mallika G, Sandip M. Socio-demographic trends in ocular cysticercosis. Acta Ophthalmol Scand. 1995;73(5):438-41.

7. Sekhar GC, Lemke BN. Orbital cysticercosis. Ophthalmology. 1997;104(10): 1599-604. Comment in: Ophthalmology. 1998;105(6):941-2.

8. Mohan K, Saroha V, Sharma A, Pandav S, Singh U. Extraocular muscle cysticercosis: clinical presentations and outcome of treatment. J Pediatr Ophthalmol Strabismus. 2005;42(1):28-33. Comment in: J Pediatr Ophthalmol Strabismus. 2005;42(5):263-4; author reply 264.

9. Trokel SL, Hilal SK. Recognition and differential diagnosis of enlarged extraocular muscles in computed tomography. Am J Ophthalmol, 1979; 87(4): 503-12.

Nos artigos enviados para publicação, o nome dos autores e suas afiliações devem estar completos. Isso facilitará a indexação e os links com as bases de dados e o CV Lates. 